\title{
TEACHER CHANGE IN A CHANGING MORAL ORDER: LEARNING FROM DURKHEIM
}

\section{Lynne Slonimsky}

University of the Witwatersrand

Email: Lynne.Slonimsky@wits.ac.za

\section{ABSTRACT}

This paper explores a curriculum paradox that may arise for teachers in postauthoritarian regimes if a radically new curriculum, designed to prepare learners for democratic citizenship, requires them to be autonomous professionals. If teachers were originally schooled and trained under the old regime to follow the orders inscribed in syllabi and textbooks authorised by the regime, then they were probably not educated for autonomous thought and practices. If so, they are caught in a double bind: either they continue to do what they have always done but then may not be able to fulfil the aims and ideals of the new curriculum, or they can wait for more detailed orders and directives that tell them exactly what to teach and how to teach. In the latter case, a dependency on external authority is maintained. The current response to this problem in South Africa is to develop programmes to strengthen teachers' content and pedagogic content knowledge and to provide highly specified curricula for teachers to follow. Deepening teachers' knowledge is one important step towards addressing the paradox, but there is a danger that teachers who are not yet sufficiently autonomous may simply treat the content and form of such programmes as yet another set of orders to be obeyed. Just over a hundred years before apartheid ended, France

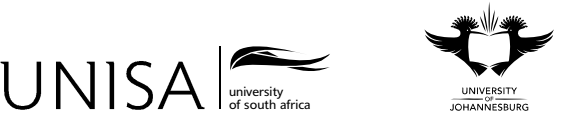

Education as Change 
was in the process of transition from despotism to democracy, and was in the process of introducing radical changes to the curriculum and the school system. Durkheim's education theory courses were explicitly designed to help teachers think about the underlying social logic of the new policies, about the significance of the changes for them, and to think about the challenges of change. Aspects of Durkheim's lectures are explored to reframe our understanding of, and our response to, the curriculum paradox with which many South African teachers are faced.

Keywords: Durkheim; education theory; curriculum change; teacher development

The last 20 years have seen a great revolution... Such a change could not take place without disturbing traditional ideas, disrupting old habits, entailing sweeping organizational changes, and without posing in turn, new problems with which we must come to grips. (Durkheim 1961, 3)

It is unlikely that a decade or so of post-apartheid experimentation within democracy would have been enough to exorcise the ghost of authoritarianism. (Ramphela 2008, 112)

\section{INTRODUCTION}

Schools commonly socialise learners into the social, political and moral values of the society. Official curriculum policies project an 'imagined community' (Anderson 1984) and ideal forms of citizenship for the nation as a whole (Carr 1998). Such policies inscribe moral and epistemic ordering principles aimed at structuring teachers' pedagogical practices towards the realisation of societal ideals.

Political changes in a nation state inevitably lead to changes in the curriculum and repressive and democratic societies cultivate substantively different moral orders that entail different approaches to curriculum. Repressive regimes cannot endure for long unless all state apparatuses - repressive and ideological - are systematically articulated to foreclose conditions of possibility for challenging the status quo and to crush resistance when it arises. Curriculum policies in repressive regimes therefore are designed to systematically thwart the development of capabilities necessary for critiquing the status quo. Repressive regimes develop and organise their education systems and curriculum policies to foster the development of heteronomous subjects - subjects who are obedient and compliant with existing rules.

While education systems in democratic societies may also serve dominant groupings' political and economic interests, they nevertheless have to create the conditions of possibility for the development of autonomy necessary for democratic citizenship and a culture of human rights. If autonomy is not developed, societies cannot function effectively as democracies.

Kant (1785/1996) introduced the concept of 'heteronomy' as a contrast to the concept of 'autonomy' in practical reason and action. For Kant, all agents have free will and a capacity for choice that they can exercise in different ways, heteronomously 
or autonomously - 'heteronomy is authority from the outside; autonomy, authority from the inside'. ${ }^{1}$ Heteronomous subjects are dependent on, and defer to the orders of others; they take the order and directions for their actions from particular authorities. In giving reasons for their choices and actions, heteronomous individuals defer to the 'dogma of a Church, to the edicts of rulers, to immediate inclinations or to the will of the majority' (O'Neill 2003, 9). Given that heteronomous subjects' practical reason and choices are grounded in the orders of someone else, Kant concluded that such individuals are under the 'yoke of tutelage' (Kant 1784/1984, 30).

In contrast, autonomous agents freely choose whether and how to follow orders by imposing an order on the orders of outside authorities. Autonomous citizens can rationally deliberate on social goods and distributive justice, can accept authority on rational grounds and will rationally critique and resist the authorities if deemed necessary. Kant explains that 'freedom in thinking signifies the subjection of reason to no laws except those which [reason] gives itself' (Kant in O'Neill 2003, 14, my insertion). The principles for action of autonomous agents are principles that any other reasonable agent could propose or evaluate as reasons for their own actions (O’Neill 2003).

The central problematic that this paper addresses is a curriculum paradox that arises in the transition from a repressive system of education in an authoritarian state to the kind of system required to develop capabilities for democratic citizenship. The paradox is that teachers who were systematically schooled and trained to be heteronomous are required to become autonomous and to promote the development of autonomous learners. This paradox exists because the official end of a sociopolitical order does not de facto create a new moral order by creating a new policy. Changes in the moral order of an education system cannot simply 'be brought about by decrees and regulation alone' (Durkheim 1977, 7). This is especially so with the attempt to develop autonomous teachers who can intelligently and critically think on their feet. To demand autonomy from teachers by writ is to force them to become autonomous. If the teachers' existing mode has been one of compliance then they will try to be autonomous because they have been told to be so. The problem is, if they have not yet developed concepts and forms of practice necessary for autonomous thought and action in the classroom, they will simply look for orders from others (download worksheets, wait for more detail from the district) or imitate what is present in teacher education programmes.

This paper explores what may be needed, over and above strengthening content and pedagogic knowledge, to enable teachers working in a period of transition from an authoritarian to a democratic society to fundamentally shift their thinking in and about their practices and to become more autonomous agents. This paper examines aspects of Émile Durkheim's 'courses for teachers'. These courses were explicitly developed to support similar shifts among French teachers at the time of

1 I am grateful to an anonymous reviewer for this succinct formulation of Kant's position. 
the political transition in France from the absolutist Second Empire to a republican democracy. Durkheim's analysis of changing curriculum and education practices in a changing moral order highlights real structural factors at the heart of the challenges for teachers called upon to change the orders of their practices in a society in the process of transition to a qualitatively different moral order. ${ }^{2}$ Durkheim's arguments with respect to changing ideals, forms of authority and knowledge in different moral orders is particularly germane to enabling teacher educators and teachers themselves to reflect consciously on the legacy of an authoritarian regime on the one hand, and to reclaim powers of reflection on the other.

\section{EDUCATION AND THE MORAL ORDER}

Every repressive regime has its own specificity. It is beyond the scope of this paper to offer empirical analyses of how specific regimes have fostered heteronomous subjects. However, a philosophical essay by Charles Peirce published in 1877 offers a succinct account of what he refers to as 'the method of authority' that authoritarian regimes tend to employ to foster heteronomous thought.

Let the will of the state act, then, instead of that of the individual. Let an institution be created which shall have for its object to keep correct doctrines before the attention of the people, to reiterate them perpetually, and to teach them to the young; having at the same time power to prevent contrary doctrines from being taught, advocated, or expressed. Let all possible causes of a change of mind be removed from men's apprehensions. Let them be kept ignorant, lest they should learn of some reason to think otherwise than they do. (Peirce 1974, 235)

Although this characterisation of conditions for the production of heteronomy was written more than a hundred years ago, Peirce could be describing the apartheid education system in the context of the entire apartheid state apparatus. This system included separate education systems for different race groups, separate curricula underpinned by the doctrine of Christian National Education that legitimated white curatorship of black people, curricula for subordinated groups that purposefully omitted powerful forms of knowledge and epistemic procedures necessary for principled critiques of the prevailing order, rigid regimens of practice backed by the legal use of corporal punishment and teacher training programmes underpinned by a pseudoscientific philosophy of education. The list is long.

To further the aims of the Apartheid regime, the majority of teachers were trained in state controlled colleges of education that limited access to specialised

2 Social structures are both material and symbolic. In this paper I do not discuss material conditions in schools, or how legacies of past inequalities may ramify into teachers' basic working conditions. These inequalities can never be addressed by education alone. 
forms of knowledge, and to procedural means necessary for the development of autonomous professionals. These colleges inculcated a pseudoscientific philosophy of education - Fundamental Pedagogics - that fused moral and epistemic discourses and legitimated a rigid regimen of practice, which was enforced in schools through regular inspections (Slonimsky 2010). In subject content areas, teachers were often taught no more than the high school curriculum itself, creating little possibility for developing disciplinary depth for themselves and their learners. Consequently, the majority of teachers in South Africa were effectively trained to be procedurally dependent on state controlled textbooks for what and how to teach. ${ }^{3}$ Studies in education emphasised obedience to authority for teachers and learners and a regimen of practice that collectivised rather than individualised learners.

Authoritarian regimes do not necessarily produce docile subjects. As Kant recognised, human beings are born with free will. Furthermore, social actions usually generate unintended consequences. Though authoritarian regimes may endure for long periods, eventually the regime cannot contain resistance and a new order is born. Resistance to Bantu Education sparked a rebellion that eventually led to the end of apartheid.

Political changes in a nation state are inevitably followed by changes in the national curriculum policy. Post-liberation policies are usually aimed at addressing the double imperative of breaking with forms of consciousness and practices inculcated in the past, and enabling the development of capabilities for democratic citizenship. The sine qua non for democracy, social justice and a culture of human rights is citizens who are capable of autonomous reason. The education system must promote conditions of possibility for the development of every member of the society as a person, it must "develop in pupils the "habit of intelligence" - the habit of confronting and resolving problems through reflective inquiry, collective deliberation and rational debate' (Carr 1998, 335). However, the education system cannot do so if 'everything that can provoke excessive initiative of intelligence [is] proscribed' (Durkheim 1956b, 132), and conformity is 'pushed to the point where it completely captures intelligence' (Durkheim 1961, 52). Teachers in open societies must be able to promote conditions for the development of deep knowledge. They cannot do this if they do not cultivate reason and initiative, and work in a morally and

3 How a curriculum shapes learners' consciousness is partially contingent on learners' social positioning, socio-cultural experiences and histories. Many of the teachers subject to this regime were actively involved in resistance movements and systematic engagement with resistance texts, and/or had been taught by missionaries, and/or had high levels of literacy. They did not become procedurally dependent, and many actively subverted Bantu education in their classrooms. 
epistemically appropriate manner with their learners to develop learners' reasoning. ${ }^{4}$

Kant (2006) proposed that everyone has free will and is in principle capable of autonomous reasoning. Yet, in the aftermath of a repressive regime, despite formal freedom, agents who have been subject to the sustained inculcation of doctrines and repression may be unable to shake off the 'yoke of tutelage' precisely because the tyranny of the previous regime lives on in the society and in consciousness. More importantly, in the case of education, he suggests that although formally free, people may struggle to become autonomous because 'reason requires trial, practice and instruction in order to progress from one stage to another' (Kant 2003, 42).

\section{THE CURRICULUM PARADOX}

Reasoned decisions concerning the ends and goals of action and the means for realising them, presuppose a capability for critical reflection on one's own actions and on possible alternatives. The development of knowledge and conscious reflection are emergent properties of individuals acting in society. If teachers are to enable the development of autonomous persons, they must be able to teach forms of knowledge necessary for the development of reason, critical reflection, deliberation and initiative in a rational and morally acceptable manner (Peters 1979). However, if teachers who were trained under a repressive regime were iteratively socialised into a doctrinaire system that legitimated the aims and ends of the ruling authorities and an inflexible regimen of practice, if they were systematically denied access to specialised forms of knowledge necessary for critique, if repression through corporal punishment was naturalised, and if this system endured for more than a generation, then it is highly likely that many teachers charged with implementing the new policies would not have developed the autonomy necessary for meeting the above mentioned conditions for promoting the development of autonomous persons. Therefore, the curriculum paradox may lead to, or intensify, a crisis in the education system as a whole. This is arguably the case in South Africa.

The first post-apartheid curriculum introduced in 1997 explicitly aimed to promote the political goals of equity, redress, a culture of human rights, democratic citizenship and social justice, and the skills and dispositions necessary for individual and social economic development. This policy effectively constituted teachers who

4 I note here that developing autonomous learners does not necessarily require that teachers have to adopt learner-directed, progressive pedagogies - what Hugo and Wedekind $(2013,139)$ call 'the imitation fallacy'. Authoritative, teacher-directed practices that afford learners systematic access to forms of knowledge that support reason can promote the development of autonomy. Furthermore, as Durkheim argues, some forms of heteronomy are necessary for the development of autonomous persons. It is a mistake to treat learners who need to learn to think autonomously as if they already are autonomous thinkers. 
had been trained to be heteronomous as highly qualified, autonomous professionals who could, and would, make their own decisions about what, when, and how to teach in their local contexts of practice. However, a significant proportion of teachers and newly appointed officials took up the policy as a new dogma, eschewing all teacherdirected learning, and educative authority in the name of 'learner-centredness' and 'group work' (Brodie, Lelliott \& Davis 2002; Taylor \& Vinjevold 1999). How to become a critical practitioner was rote learnt and rote implemented.

Subsequently, there have been further changes in curriculum, culminating in the current Curriculum and Assessment Policy (CAPS). CAPS is highly prescriptive of content, method and pacing, and has arguably closed down spaces for teacher discretion. So while the curriculum shifts indicate recognition of the fact that autonomy cannot be decreed, they do little to support moves from heteronomy to autonomy.

A recent study of poorly performing schools (Taylor, Draper, Muller \& Sithole 2012) proposes that it is important to distinguish between schools and teachers who won't do what is expected of them due to ill-discipline and poor leadership and management, and those who can't teach appropriately because they lack sufficient knowledge of the school subject, knowledge of the curriculum and knowledge of how to teach the subject (19-27). My argument is that the ongoing crisis in education is not about teachers who can't and/or won't engage appropriately with the curriculum. Rather, the curriculum paradox and the crisis it generates is structural - an emergent property of the process of transition from authoritarian to democratic societies.

As much as the teachers may be committed to, and wish to fulfil the aims and intentions of the new policies, they cannot. If they try to fulfil the policy requirements by resorting to what they have always done, they will foreclose necessary conditions for the development of autonomous agents. If they recognise that the old cannot hold, but do not have access to alternative epistemic and regulative discourses for establishing different orders of practice, they may completely lose their own authority, a fundamental condition for any teaching and learning thus generating a crisis in the education system as a whole. ${ }^{5}$

Bourdieu points out that 'one cannot at the same time denounce inhuman conditions...and credit the people placed in such situations with the full accomplishment of their human potentialities' (Bourdieu 1998, 136). That said, it is difficult to talk about the effects of authoritarian education on teachers' subjectivities without doing further symbolic violence. Yet, failure to make this problematic a

5 I am not going to address the problem of teachers who 'can' but 'won't' in this section. Complexly intertwined sets of contemporary and historical conditions and dynamics underpin widespread belligerence and dereliction of duty in all sectors of South African society, not only in the education sector. However, some reasons for this phenomenon should become clearer on the basis of Durkheim's arguments with respect to authority, knowledge and the moral order to be explored in this paper. 
conscious object of reflection may result in ways of addressing the crisis that bypass the problem of heteronomy and the constraints and possibilities of enabling the development of autonomy in educators.

Durkheim's social realist 'science of morality', and his lectures to teachers, particularly those on moral education, provide us with a means of thinking about the significance and implications of how the changing moral order shapes teachers' consciousness and practices, especially when the shift is from heteronomy to autonomy. Durkheim saw educational theory as the gateway to support shifts among teachers and I now turn to his socio-epistemic analysis.

\section{DURKHEIM'S EDUCATION COURSES FOR TEACHERS}

Durkheim developed his sociological theory and taught education theory in the context of a changing moral order in French society from the absolutist Second Empire to democracy in the Third Republic. In 1886 the new republican government in France secularised the education system, and introduced changes to the curriculum in schools. These reforms were viewed as both the means of ending church control of education, and promoting the ideals of the nascent republic. Prior to this, in 1882, the republican minister of education had proposed that when all French youth have been taught in a secular education system 'we shall have nothing more to fear from returns to the past' because, he suggested, these 'countless young reserves of republican democracy, trained in the school of science and reason... will block retrograde attitudes with the insurmountable obstacle of free minds and liberated consciences' (Ferry 1892 cited in Jones 1999, 38).

To advance these aims, the state supported the development of a course in pedagogy for primary school teachers at the University of Bordeaux. This opened the way to Durkheim's first appointment in the academy, which was to develop and teach these courses first at Bordeaux and then to secondary school teachers at the Sorbonne.

Jones (1999) argues that the impetus behind Durkheim's lectures on moral education was what he viewed as a crisis in the nascent republic and in the education system, and the need for a coherent moral language to enable the realisation of the ideals of the new republic. There is an apparent tension here: on the one hand Durkheim wanted to develop a science of morality; on the other he had a political agenda. How did he reconcile the two? He viewed science as a means of clarifying the conditions of possibility for realising the social ideals of the new order. Durkheim asserted that

to correct reality one must first know it. Before morality can aspire to the perfection of mores, a science of mores must be created otherwise the ideal which it constructs can only be a work of poetic fantasy, an entirely subjective conception which could never occur since it bears no relation to facts. (Durkheim 1978, 220) 
Durkheim approached morality as a sociologist, not a moralist. He was not concerned with debates about the 'right' and the 'good' but with morality as a social fact - a phenomenon that exists in all societies and that fundamentally influences curriculum. The discussion that follows focuses on Durkheim's analysis of the changing moral order in French education, the explanations he gave to teachers for why they need education theory, and the methodology he modelled in his lectures. These three aspects of his lectures are instructive for engaging with the problematic at stake in this paper, namely changing the orders that ground teachers' practices following liberation from a repressive regime.

\section{DURKHEIM AND THE IMPORTANCE OF EDUCATION THEORY}

If teachers are to reorganise and reconstruct their conceptions and practices, they must overcome their taken-for-granted beliefs about education and teaching premised on their own schooling and their extended observation of their own teachers - the bearers of the old order. The first step is reflection, which is 'the scourge and enemy of routine' (Durkheim 1977, 5). Reflection alone can

prevent habits from becoming immutable and sacrosanct...can keep them vital and sustain them in such a condition of flexibility and malleability that they will be able to change, evolve and adapt themselves to variations in circumstance and situation. In so far as one restricts the role of reflection, in education one condemns it to stagnation. (Durkheim 1977, 5)

Reflection is the gateway to changing taken-for-granted beliefs and practices. It constitutes capabilities to change practices consciously and volitionally in response to changing conditions. However it cannot be 'haphazard', it must be 'applied as methodically as possible to educational matters' $(1977,4)$. Durkheim proposed that education theory is key to promoting the development of systematic reflection in and of practice. In fact, by education theory, Durkheim meant 'reflection applied as systematically as possible to educational matters' (Durkheim 1977, 4). Education theory systematically combines 'all the data that science, and the most methodical documented thinking, puts at its disposal as a guide to action' (Durkheim 1961, 1). Education theory is not a body of theories to be applied to practice but a set of procedures for working with facts, and ordering one's thinking on particular problems or objects of analysis - it develops 'ways of conceiving of education' (Durkheim 1956a, 91). For Durkheim 'to use reflection methodically is to do education theory' (Durkheim 1977, 5, my emphasis).

Durkheim engaged teachers in reflecting on and reorganising their concepts and practices through both the content and the method of his courses. He engaged explicitly with the very problematic that his course was designed to address - that of changing pedagogy in a changing moral order. In the first half of his course (ten 
lectures) he systematically excavated how and why the changes had happened, how the changes related to the old and what needed to be developed for the new. In order to build a notion and practice of reasoned accountability among the teachers, he systematically accounted for the current problematic and the ways in which it could be transformed. In the second half of the course, he systematically drew out the implications for the development of autonomous practice - the development of discipline in schools, belonging and accountability to communities, and the significance and role of disciplinary knowledge. The course built a notion of the facts of the moral order and cultivated forms of reasoning with and about those facts. In other words, he developed a social realist analysis of the changes in society and in education.

\section{DURKHEIM'S SOCIAL REALIST SCIENCE OF MORALITY}

The fundamental principle of social realism is that social phenomena are real. These entities exist regardless of whether we have knowledge of them; they have properties and powers of their own. Underlying dynamic connections between these entities may activate their respective powers and cause new properties and powers to emerge. Knowledge of these connections can be constructed scientifically on the basis of systematic analysis of empirical evidence and inferences subject to rigorous methods of testing. Sociology is concerned with the study of society through an investigation of social facts. To say that social phenomena are social facts means that for Durkheim they are grounded in, but not reducible to, natural properties and powers. They are in fact emergent properties of individuals in joint, communal activities. Society is a social fact:

It has its own nature that is greater than, and goes beyond us, but at the same time it enters every part of us. It is outside of us and envelops us, and is everywhere as an aspect of our nature. (Durkheim 1961, 71)

Moreover, morality is real, being a particular set of social facts that differ in different societies. In all societies there are rules, norms and mores, which are associated with the use of the word 'moral'. In contrast to Kant, who presents morality as a trans-historical phenomenon, Durkheim offered a socio-cultural account of morality. Kant, by Durkheim's account $(1984,1961)$, failed to recognise that both the ideal of autonomous persons and the actual conditions of possibility for their development are products of changing forms of moral and epistemic authority in societies with an advanced division of labour.

In a lecture to teachers on pedagogy, society and moral education, Durkheim asserted that "liberty is the daughter of authority properly understood...to be free is not to do what one pleases; it is to be master of oneself, it is to know how to act with reason and to do one's duty' (Durkheim 1956a, 89). This is because morality 
is an emergent property of the relations between individuals in collective life: 'We are only moral beings because we live in society' (Durkheim 1984, 331). Morality is 'a body of ideas that soar above the individual, which come into being and sustain themselves only through the interaction of a plurality of individuals' (Durkheim 1961, 123). They 'force man to take account of other people' (Durkheim 1984, 331) thereby enabling social cohesion. Moral conduct 'is a matter of abiding by a norm, determining what conduct should obtain in a given instance even before one is required to act' (Durkheim 1961, 23), and it therefore pre-exists particular agents. In the course of acting, human beings revivify social facts and collective activities generate new ideals and social forces. However, 'time is needed for a form of behavior or belief to attain the necessary level of generality or crystallization, and time also to lose it' (Durkheim 1984, 233).

Durkheim argued that the transition to a secular education system had been seriously undermined by the fact that the task of creating a secular moral order grounded in reason had been conceived as a purely negative operation, of taking out, or stripping away all beliefs and practices associated with the old authorities. This approach focused on the surface manifestations of morality, but failed to take account of underlying causal dynamics and properties of morality. In order to understand how the dynamics of the old order were both constitutive and constraining of the new, Durkheim developed a systematic account of the key aspects of morality, which account for how the new must and can be premised on and transform what has gone before. Durkheim argued that there are two necessary conditions for any morality: community and discipline.

Since moral conduct is oriented to the collective, it presupposes a feeling of identification and affiliation with others. Underpinning the moral temperament is a feeling of a bond or attachment to the social group to which one belongs and a commitment to its ideals. One would not subordinate one's activities to the discipline of the group without a feeling of connectedness to the group and the ideals that the group projects and revivifies.

This connectedness to a group cannot develop without iterative participation in the activities and routines of the group. Participation in these activities generates 'powerfully formed habits', or 'internal forces within the individual' (Durkheim 1961, 9), which become the basis of 'a line of conduct' (28). Therefore, morality is premised on discipline, by which Durkheim meant learning to conduct oneself within and in relation to the morality of the group, which cannot happen without sustained routine and regularity.

Given that morality is 'that influence, which imposes upon us, all of the moral power that we acknowledge as superior to us' (Durkheim 1961,29) and that 'the idea of authority plays an absolutely preponderant role' in moral conduct (29), agents cannot develop self-mastery without an orientation to regularity and routine. 'Selfmastery', he argued, is 'the first condition of all true power, of all liberty worthy 
of the name' (29), because it is 'the indispensable condition for the emergence of a reflective individual will' (49).

Moral regulations impose regularity and shape behaviour, therefore individuals do not have to invent the aims and forms of day-to-day conduct de novo. It is thus possible for human beings to develop an economy of effort and a fluidity of practice in daily activities. Moral rules are therefore not merely constraining - they are also enabling. More than this, moral rules are psychically containing. As Durkheim points out:

If moral rules lack the necessary authority to exert, to a desirable degree, a regulatory influence on behaviour...we see a society gripped by dejection and pessimism. (Durkheim 1961, 68)

Too much regulation and stability constrains initiative and an imagination for the possible, which can result in fatalism, or extreme altruism in which one completely subordinates one's own sense of self to the interests of the group. Too few limits result in extreme anxiety (anomie) or extreme detachment (egoism). At their extreme, individuals become so detached from reality that they kill themselves. This is why Durkheim argued that suicide rates are indices of a breakdown of moral regulation in society.

He is clear that what is needed is a balance between regulations that provide stability and those that enable change, because societies are not static. Therefore, morality must enable stability, but has to be sufficiently flexible for change to be possible.

This requires that morality cannot be internalized in such a way that it is beyond criticism, or reflection. Individuals while conforming must take account of what they are doing and conformity must not be pushed to the point where it completely captures intelligence. (Durkheim 1961, 52)

The above mentioned aspects of morality imply a continuum between heteronomy and autonomy. So, while individuals are learning to subordinate themselves to the discipline of the group, or to an epistemic discipline or practice, there will be a time when they will have to be heteronomous in so far as they will have to accept the authority of the regulations on trust. As people develop increasing self-mastery and reflective capacities, they will develop more capabilities for choice.

\section{THE CONDITIONS OF POSSIBILITY FOR THE ESTABLISHMENT OF A DEMOCRATIC MORAL ORDER}

Having established that all morality is contingent on discipline and a spirit of attachment, Durkheim added that a special condition for a democratic moral order is the exercise of reason. He explained that whereas early moral orders were grounded 
in religious rites which sacralised supernatural elements, and the church grounded its authority in God, a secular, democratic society cannot be grounded in sectarian doctrines; it must be grounded in the authority of reason and is contingent on the development of persons capable of autonomous thought. 'To act morally', he explained, 'it is no longer enough - to respect discipline and be committed to a group...beyond this we must have as clear and complete awareness as possible of the reasons for our conduct' (Durkheim 1961, 120).

Though all morality is grounded in a power that we acknowledge as superior to us, in the course of history there have been fundamental changes in human beings' conceptions of the world, moral virtues and humanity and therefore morality may be grounded in appeals to different authorities. In advanced economies, the division of labour necessitates increasing occupational specialization. Increased specialization leads to increasing individualization and differentiation, potentially threatening social solidarity. In order to promote solidarity, modern societies have developed an ideal of humanity, which enables members of society rationally to recognise that despite their differences 'there is one respect in which they resemble each other... they are all human beings' (Durkheim 1956a, 121). In modern societies, 'the dignity of the person' (121) endows the right of each individual to develop autonomous thought and 'any restriction of our conscience seems immoral because it violates our personal autonomy' (Durkheim 1984, 122). Durkheim's principle is not one of egoistic individualism but moral individualism because society defines the individual.

The orientation to human rights and the individual goes hand in glove with the development of autonomous reason. A secular morality, which valorises persons, must be grounded in reason. He explains that

When one feels the need of liberating individual thought, it is because in a general way one feels the need of liberating the individual. Intellectual servitude is only one of the servitudes that individualism combats. (Durkheim 1961, 12)

He explains that

The development of individualism has the effect of opening moral consciousness to new ideas and rendering it more demanding. Since every advance that it makes results in a higher conception, a more delicate sense of the dignity of man, individualism cannot be developed, without making apparent to us as contrary to human dignity, as unjust, social relations that at one time did not seem unjust at all...For injustice is unreasonable, and absurd, and consequently we are the more sensitive to it as we are more sensitive to the rights of reason. (Durkheim 1961, 12)

For Durkheim autonomy lay in 'enlightened assent' to the moral order if we know it is in order (Durkheim 1961, 120). What grounds this assent and how does it enable respect for human dignity? Durkheim was unequivocal that these capabilities and virtues are grounded in the development of forms and contents of knowledge that 
can only be developed through systematic learning of knowledge: 'To teach morality is neither to preach nor indoctrinate, it is to explain' (Durkheim 1961, 120).

Knowledge is the constitutive condition for autonomy. We can freely choose to conform to the moral order to the extent to which we can recognise that the moral order is rational and 'is what it ought to be' (Durkheim 1961, 117), but we can also reject it if 'it is not based on the order of things' (117). However, the only way we can know that it is 'out of the order of things' is by learning to think on the basis of the powers of rational reasoning, and scientific understanding. In other words, we must be committed to an ongoing quest for a deeper understanding of real properties, powers, and generative mechanisms of natural and social facts, and a deepening knowledge that despite our apparent differences we all share a common humanity and are all entitled to dignity, respect and social justice. As Durkheim put it, 'we liberate ourselves through understanding; there is no other means of liberation' (Durkheim 1961, 116).

\section{LEARNING FROM DURKHEIM}

This paper set out to characterise a curriculum paradox that is generated for teachers in the transition from a repressive system of education in an authoritarian state, to the kind of education system necessary for enabling the development of democratic citizens. It has explored aspects of Durkheim's lectures to teachers, on the grounds that they offer a powerful analytic means for describing the curriculum paradox at stake in teacher change in a changing moral order. The lectures are also instructive in explaining why deepening teachers' content and pedagogical knowledge cannot suffice for engaging with the paradox.

Durkheim recognised that official policies cannot change teachers' practices by fiat. He understood that unless teachers develop a reasoned understanding of the inner logics of new policies, they cannot but interpret them superficially in relation to what they know and can do. He recognised that if teachers cannot learn to think systemically and critically in general, and more specifically about education, they will be subject to whatever the latest policy prescribes, whether or not it is in fact reasonable. This is the logic behind his assertion that

It is not enough to prescribe to [teachers] in precise detail what they will have to do; they must be in a position to assess, and appreciate these prescriptions, to see the point of them and the needs they meet. In brief they must be familiar with the problems for which these prescriptions provide provisional solutions. This means that it is essential to initiate them into the great problems involved in education for which they will be responsible, no less than the methods whereby it is proposed to solve them so that they may be able to make up their own minds with knowledge of the issues involved. Such an initiation can only come from a study of educational theory. (Durkheim 1977, 4) 
Durkheim did not teach education theory as a parade of paradigms or theorists; he also did not present the teachers with the new policies and syllabi; and he did not give teachers prescriptions for practice. He began his course on moral education by proclaiming that the introduction of the new policy required new forms of consciousness and practices that could not be changed by decree. The point is that after making this pronouncement he went on to develop a very principled, evidentially warranted explanation of why these qualitatively new forms of consciousness and practices were necessary, but could not be developed by simply 'stripping away' everything from the old order. He supported the argument by drawing on a vast body of evidence from history, psychology and his own sociological studies. He took the teachers through a sustained, progressively deepening inquiry into the history, underlying social-causal dynamics, and inner logic of the changes before analysing the implications for their practices. Over the course of twenty-one lectures, he traced socio-historical forces at the heart of the new moral order and why these had generated new imperatives for education. In the course of explaining why and how policy changes are socio-historically shaped, he explicitly pointed out that the teachers' subjectivities, forms of consciousness, and practices, had also been shaped socio-historically by the old political and moral order and could not simply be wished away. Both discipline and a sense of belonging to society are necessary conditions for any moral order. These, and the knowledge disciplines, are indispensable for the development of autonomous thought necessary in a secular moral order.

Durkheim's methodology was as important as the content of his course. He did not teach in a 'learner-centred' way. He was unequivocally authoritative, but offered teachers conditions for autonomy within his lectures by modeling 'or exteriorising' sustained and systematic thought, and what it means to account rationally for one's position on a curriculum question. By all of these means he offered teachers access to facts, forms of knowledge and procedures for developing forms of thought necessary for developing critical thought, and a culture of human rights in a democratic society.

Education theory is an important means of enabling teachers to form an enlightened understanding of curriculum policies and their implications for practice, but it cannot do this if it is taught as a set of dogmas. It must be informed by procedures of enquiry that can enable teachers to distinguish between the actual, the real and the possible, to comprehend that there are structural reasons for some of the challenges they are confronting, and real conditions of possibilities for change. Education theory can enable teachers to understand that education systems and policies have social logics, and histories. More than this, education theory can enable teachers to understand that their being has been shaped by, but is not determined by, the past, and that they can shape the future. For Durkheim, education theory is the most powerful means of promoting critical reflection, rational attachment, and a means of self-understanding. 
It is of deep concern that the crisis in the education system in South Africa has deepened the more there has been a turn away from theory, and a greater emphasis on strengthening subject knowledge or pedagogy. Both are necessary; neither is sufficient for meaningful change. Change can only begin when teachers can bring reason to bear on their actions and can give a reasoned account of their reasoning. The only way in which teachers can produce autonomous citizens for a democratic state is if they become autonomous themselves. Until such time as policies intended to improve the education system recognise that strengthening teachers' subject and pedagogical knowledge is necessary, but not sufficient, to set them on the path to autonomy, the process of transformation has not truly begun. Durkheim provides us with a different way of thinking about the problematic of changing teachers in a changed and changing society.

In conclusion, this paper has explored one set of structural conditions that have generated a curriculum paradox for a significant proportion of South African teachers, and an ongoing crisis in the South African education system. It has argued that we can learn a lot from the way Durkheim worked with teachers both to understand and begin to surmount those structural conditions. If autonomy is to be legislated, conditions must be put in place for the development of deep knowledge, systematic reasoning and reflection, and critique. Only then can teachers begin to respond autonomously to the command to be autonomous.

\section{ACKNOWLEDGEMENTS}

Special thanks to Hilary Janks, without whom I could not have begun to work with my own authority and authoring issues, and to Yael Shalem, Wayne Hugo and Karin Brodie for insightful comments.

\section{REFERENCES}

Anderson, B. 1984. Imagined communities: Reflections on the origin and spread of nationalism. London: Verro.

Bourdieu, P. 1998. Practical reason. Cambridge: Polity.

Brodie, K., A. Lelliott and H. Davis. 2002. Forms and substance in learner-centred teaching: Teachers' take-up from an in-service programme in South Africa. Teaching and Teacher Education 18(5): 541-559.

Carr, W. 1998. The curriculum in and for a democracy. Curriculum Studies 6(3): 323-340.

Durkheim, É. 1956a. Education and sociology. Translated by S.D. Fox. NewYork: Free Press.

Durkheim, É. 1956b. Pedagogy and sociology. In É. Durkheim. Education and sociology, 113134. New York: Free Press.

Durkheim, É. 1961. Moral education: A study in the theory and application of the sociology of education. Translated by E.K.Wilson and H. Schnurer. Glencoe: Free Press. 
Durkheim, É. 1977. The evolution of educational thought: Lectures on the formation and development of secondary eductation in France. Translated by P. Collins. London: Routledge \& Kegan.

Durkheim, É. 1978. Émile Durkheim on institutional analysis. Translated and Edited by M. Traugott. Chicago: University of Chicago Press.

Durkheim, É. 1984. The division of labour in society. Translated by W.D. Halls. London: MacMillan.

Jones, R.A. 1999. The development of Durkheim's social realism. Cambridge: Cambridge University Press.

Hugo, W. and V. Wedekind. 2013. Six failures of the pedagogic imagination: Bernstein, Beeby and the search for an optimal pedagogy for the poor. Southern African Review of Education 19(1): 139-157.

Kant, I. 1784/1984. An answer to the question: What is enlightenment? Translated by L.W. Beck. In German aesthetic and literary criticism: Kant, Fichte, Schelling, Schopenhauer, Hegel. Edited by D. Simspon. Cambridge: Cambridge University Press.

Kant, I. 1785/1996. Groundwork of metaphysics of morals. In Practial Philosophy. Translated and edited by M.J. Gregor, 37-108. Cambridge: Cambridge University Press.

Kant, I. 2003. Idea for a universal history with a cosmopolitan purpose. In Kant: Political writings. Edited by H.S. Reis. Cambridge: Cambridge University Press.

Kant, I. 2006. An answer to the question: What is enlightenment? In Practical Philosophy. Edited by M.J. Gregor, 17-22. Cambridge: Cambridge University Press.

O’Neill, O. 2003. The inaugural address: Autonomy: The emperor's new clothes. Proceedings of Aristotelian Society, Supplementary volume 77:1-21.

Peirce, C.S. 1974. Collected papers of Charles Sanders Peirce. Cambridge, MA: Harvard University Press.

Peters, R.S. 1979. Ethics and education. London: George Allen and Unwin.

Ramphele, M. 2008. Laying ghosts to rest: Dilemmas of the transformation in South Africa. Tafelberg: Nb Publishers.

Slonimsky, L. 2010. Reclaiming the authority of the teacher. In Retrieving teaching: Critical issues in curriculum pedagogy and learning. Edited by Y. Shalem and S. Pendlebury, 41-55. Cape Town: Juta.

Taylor, N., K. Draper, J. Muller and S. Sithole. 2012. The state of literacy teaching and learning in the foundation phase. Pretoria: Department of Basic Education.

Taylor, N. and P. Vinjevold, eds. 1999. Getting learning right: Report of the President's Education Initiative Research Project. Johannesburg: Joint Education Trust. 